\title{
Self-Regulation of Emotion in Students in Yogyakarta Indonesia: Gender Differences
}

\author{
Said Alhadi ${ }^{1}$, Wahyu Nanda Eka Saputra ${ }^{1 *}$, Purwadi Purwadi ${ }^{1}$, Siti Muyana ${ }^{1}$, \\ Agus Supriyanto ${ }^{1}$, Dwi Fatmawati ${ }^{2}$ \\ ${ }^{1}$ Department of Guidance and Counseling, Faculty of Teacher Training and Education, \\ Universitas Ahmad Dahlan, Pramuka Street No. 42, Yogyakarta, Special Region of Yogyakarta, Indonesia 55161 \\ ${ }^{2}$ International Development and Cooperation (IDEC), Hiroshima University, \\ 1-5-1 Kagamiyama, Higashi-Hiroshima, Japan 739-8529 \\ *corresponding author, e-mail: wahyu.saputra@bk.uad.ac.id
}

Article received: March $9^{\text {th }} 2019$; revised: May $9^{\text {th }} 2019$; accept: May $16^{\text {th }} 2019$

\begin{abstract}
The purpose of this study was to identify whether there are differences in self-regulation of emotion skills of male and female students. This study is a comparative study with a sample of 796 students (452 males, 344 females). The sample selection is taken using cluster and random sampling technique. The instrument used is the scale of self-regulation of emotion. Data analysis used to identify differences in self-regulation of emotion skills of male and female students is independent samples test. The findings of the study indicate that there is a significant difference between the self-regulation of emotion skills of male and female students. This study recommends counseling service to improve selfregulation of emotion skills.
\end{abstract}

Keywords: self-regulation of emotion; gender differences; counseling sevices

\begin{abstract}
Abstrak: Tujuan dari penelitian ini adalah untuk mengidentifikasi apakah terdapat perbedaan selfregulation of emotion antara siswa laki-laki dan perempuan. Penelitian ini adalah penelitian komparatif dengan sampel 796 siswa (452 laki-laki, 344 perempuan). Pemilihan sampel diambil menggunakan teknik cluster and random sampling. Instrumen yang digunakan adalah skala self-regulation of emotion. Analisis data yang digunakan untuk mengidentifikasi perbedaan self-regulation of emotion siswa lakilaki dan perempuan adalah independent samples test. Temuan penelitian menunjukkan bahwa terdapat perbedaan yang signifikan antara self-regulation of emotion siswa laki-laki dan perempuan. Studi ini merekomendasikan layanan konseling untuk meningkatkan self-regulation of emotion siswa.
\end{abstract}

Kata kunci: self-regulation of emotion; perbedaan gender; layanan konseling

\section{INTRODUCTION}

Adolescence is a transition period from childhood to adulthood where the search for identity begins (Hopkins, 2014). It is a phase when someone experiences great mental pressure and when major physical, intellectual and emotional changes happen. These changes may result in sadness and vacillation which may be further extended as well create conflict with surrounding or environment. This condition then forces adolescents to maximize their potentials to manage their emotions so that maladaptive behavior can be well avoided. Research shows that the ability to control emotion can enhance students' academic success (Gage, Adamson, MacSuga-Gage, \& Lewis, 2017; Shah, Sanisara, Mehta, \& Vaghela, 2017; Sointu, Savolainen, Lappalainen, \& Lambert, 2017; Wigelsworth, Qualter, \& Humphrey, 2017).

One's ability to control his own emotion is often referred to as self-regulation of emotion. Selfregulation of emotion is an intrinsic experience of managing emotion which then informed on cognitive abilities to provide an influence and emotional feelings over the behavior (Vandekerckhove, Von Scheve,

How to cite: Alhadi, S., Saputra, W. N. E., Purwadi, P., Muyana, S., Supriyanto, A., \& Fatmawati, D. (2019). Self-Regulation of Emotion in Students in Yogyakarta Indonesia: Gender Differences. Jurnal Kajian Bimbingan dan Konseling, 4(3), 82-87. https://doi.org/10.17977/ um001v4i32019p082 
Ismer, Jung, \& Kronast, 2008). Emotions occur because there is a stimulus to a person and then reflected in his behavior. Emotion regulation process can occur consciously or unconsciously and function to reduce; improve; maintain; and replace certain emotions (Philippot \& Feldman, 2004a, 2004b).

However, many adolescent are in fact unable to control their emotions and this condition is known as aggressive behavior (García-Sancho, Salguero, \& Fernández-Berrocal, 2017; Huesmann et al., 2017; Sullivan, Garthe, Goncy, Carlson, \& Behrhorst, 2017; Valois, Zullig, \& Revels, 2017) and bullying (Jenkins, Demaray, \& Tennant, 2017; Zych, Farrington, Llorent, \& Ttofi, 2017). Aggressive behavior is a problem that needs more attention. The research shows that around $72,16 \%$ students committed physical crime which involve violence, while the remaining $27,84 \%$ tend to commit non-violent crime (Shelton, Sampl, Kesten, Zhang, \& Trestman, 2009). Other research also shows that $72 \%$ of interviewed respondents admitted that they committed physical attacks to their mother; $16 \%$ attacked and threatened their father; and 5\% attacked or threatened their brother or sister or their relatives (Routt \& Anderson, 2011). A research about bullying shows that nine percent of respondents were victims of bullying, $9 \%$ were bullies, and 3\% were bully-victims (Spriggs, Iannotti, Nansel, \& Haynie, 2007).

Aggressive behavior in Indonesia as a result of the poor self-regulation of emotion of students also occurred and became the concern of many parties. In Indonesia, research was also conducted on the aggressive behavior of students in Yogyakarta vocational high schools, which showed that $5 \%$ of students were categorized as very aggressive; $26 \%$ of students were aggressive; $40 \%$ of students were quite aggressive; $21 \%$ of students were fairly aggressive; and $8 \%$ of students were somewhat aggressive (Saputra \& Handaka, 2018). Other studies on junior high schools in Yogyakarta showed the data on aggressive behavior of $1 \%$ of students were categorized as very aggressive; $13 \%$ of students were aggressive; $37 \%$ of students were quite aggressive; $43 \%$ of students were fairly aggressive; and $6 \%$ of students were somewhat aggressive (Alhadi, Purwadi, Muyana, Saputra, \& Supriyanto, 2018). In fact, in Yogyakarta, the level of aggressive behavior in female students tends to be equal as in male students (Saputra, Hanifah, \& Widagdo, 2017). This draws attention from many parties about this complicated problem of aggressiveness in Indonesia.

It has been clearly shown that there are differences between the ideal condition and the real condition found in the field. Students should have been able to regulate their emotions to enhance their academic success. Many students tend to display maladaptive behavior as a result of their inability to manage their emotion. This research aims to identify the difference of self-regulation of emotion between male and female students. Self-regulation of emotion indeed plays a vital role in enhancing academic achievements, yet it is hard to acquire.

Several previous studies were conducted to identify differences in the level of self-regulation of emotion in male and female students. The previous research concluded that female has a better emotion management than male (Perry-Parrish et al., 2017). Another research stated the similar that female has a higher ability to express happiness and shyness than male (Panjwani, Chaplin, Sinha, \& Mayes, 2016). Other studies showed different results; male is more capable to control their emotion than female (Trives, Bravo, Postigo, Segura, \& Watkins, 2016). Another research suggested that the decrease in emotional intelligence was more often experienced by female than male (Gomez-Baya, Mendoza, Paino, \& de Matos, 2017).

This research can be used as the basis for a suitable and meaningful counseling intervention. Providing counseling to male and female students to improve their self-regulation of emotion should be tailored to their needs. Therefore, self-regulation of emotion is expected to increase along with the decrease in aggressive behavior in students.

\section{METHOD}

This research is a comparative research whose objective is to compare the level of self-regulation of emotion ability between male and female student. This research is designed as a comparative research with population of 12,984 junior high school students in Special Region of Yogyakarta. The sample of this research is taken with cluster and random sampling. The minimum limit in cluster and random sampling is 399.9969 or 400 students. The error standard is $5 \%$. It aims to give more maximum sample size. The sample used in this research is 796 students which are largely spread in junior high school in Special Region of Yogyakarta, Indonesia. 
The instrument used in this research is self-regulation of emotion scale with cognitive reappraisal and expressive suppression indicators (Hofmann, Carpenter, \& Curtiss, 2016). It is adjusted with the multicultural characteristic of the research subject by using validity and reliability test. The implementation of self-regulation of emotion scale is equally adjusted with the psychological development of middle school students. The comparison between the two becomes the findings in potential and competence development, problem prevention and its solvency. Self-regulation of emotion scale is not tested for validity and reliability because this scale is the result of adoption that has been tested for validity and reliability. In addition, the scale of self-regulation of emotion is declared appropriate for use after being assessed by experts.

The data analysis was done by using independent sample test technique with SPSS 20.00. The aim of this analysis is to identify the difference in the level of self-regulation of emotion ability between male and female students. The result will be used to know the difference using cognitive reappraisal and expressive suppression indicator.

The study was conducted on junior high school students in Special Region of Yogyakarta, Indonesia. The first thing to do is to coordinate with school counselors to determine the sample involved in the study. Second, measure the level of self-regulation of emotion in both male and female samples. Third, conduct analysis of research data to identify different levels of aggression behavior in male and female students. All the data were entered into the SPSS 20.00 and all the necessary analyses were conducted.

\section{RESULTS}

The result of data analysis with independent sample test formula is presented in table 1 and table 2. In the first output, group statistic, the researcher concluded that $\mathrm{N}$ is 452 for male student and 344 for female student. The mean in male group is 37.1460 and 38.1134 in female group. In table 2 it can be seen that $F$ is 3.975 with significance level of 0.057 which means $0.05(0.057>0.05)$. It means that the variant of population group is homogeny. Thus, the homogeneity requirement for comparative analysis is fulfilled. From the data analysis, the coefficient is -2.344 with probability of 0.019 . When it is compared to 0.05 , the probability value is smaller. It means that there are differences in self-regulation of emotion between male and female students. Based of the group average, female students possess higher and better self-regulation of emotion ability than male students.

Table 1. Group Statistics

\begin{tabular}{lccccc}
\hline & Gender & N & Mean & Std. Deviation & Std. Error Mean \\
\hline Self Regulation & Men & 452 & 37.1460 & 5.99896 & 0.28217 \\
Emotion & Women & 344 & 38.1134 & 5.44963 & 0.29382 \\
\hline
\end{tabular}

Table 2. Independent Samples Test

\begin{tabular}{|c|c|c|c|c|c|c|c|c|c|c|}
\hline & & $\begin{array}{r}\text { Leve } \\
\text { Test } \\
\text { Equal } \\
\text { Varia }\end{array}$ & $\begin{array}{l}\text { ne's } \\
\text { for } \\
\text { ity of } \\
\text { nces }\end{array}$ & & & t-test for & Equality & of Mean & & \\
\hline \multirow{4}{*}{$\begin{array}{l}\text { Self } \\
\text { Regulation } \\
\text { Emotion }\end{array}$} & \multirow[b]{3}{*}{$\begin{array}{l}\text { Equal } \\
\text { variances } \\
\text { assumed }\end{array}$} & \multirow[t]{2}{*}{$\mathrm{F}$} & \multirow[t]{2}{*}{ Sig. } & \multirow[t]{2}{*}{$\mathrm{T}$} & \multirow[t]{2}{*}{$\mathrm{df}$} & \multirow[t]{2}{*}{$\begin{array}{l}\text { Sig. } \\
\text { (2-tailed) }\end{array}$} & \multirow{2}{*}{$\begin{array}{l}\text { Mean } \\
\text { Differ- } \\
\text { ence }\end{array}$} & \multirow{2}{*}{$\begin{array}{l}\text { Std. } \\
\text { Error } \\
\text { Differ- } \\
\text { ence }\end{array}$} & \multicolumn{2}{|c|}{$\begin{array}{l}95 \% \text { Confidence } \\
\text { Interval of the } \\
\text { Difference }\end{array}$} \\
\hline & & & & & & & & & Lower & Upper \\
\hline & & 3.975 & .057 & -2.344 & 794 & .019 & -.96735 & .41270 & -1.77748 & -.15723 \\
\hline & $\begin{array}{l}\text { Equal } \\
\text { variances } \\
\text { not } \\
\text { assumed }\end{array}$ & & & -2.375 & 769.579 & .018 & -.96735 & .40737 & -1.76704 & -.16766 \\
\hline
\end{tabular}




\section{DISCUSSION}

There are differences in self-regulation of emotion between male and female students. The result in this research is also supported by the previous research. The earlier research concluded that female has better emotion management than male (Perry-Parrish et al., 2017). However, these previous studies emphasized emotion management on anger aspects. Whereas this research specifically identifies male and female student self-regulation of emotion.

Another research stated similarly in telling that female has higher ability to express happiness and shyness than male (Panjwani et al., 2016). Those research results show that female manage and regulate their emotion better when they are in certain situation. Female tend to manage their anger and emotion so that maladaptive behavior can be avoided. However, these previous studies emphasized the expression of happiness and shyness. While in this study emphasizes the self-regulation of emotion, one of which is an expression of happiness and shyness.

However, some researches show the opposite. The previous research suggested that male has better ability to control their emotion than female (Trives et al., 2016). Another research suggested that the decrease in emotional intelligence is more often experienced by female than by male (Gomez-Baya et al., 2017). They imply that male has better emotion management ability. Male is believed to have more maturity to control their emotion than female when they are in a difficult situation.

Someone's ability to manage emotion significantly influence aggression behavior. The research suggested that borderline personality disorder; physical; and psychological aggression are fully mediated by the difficulty to regulate emotion (Scott, Stepp, \& Pilkonis, 2014). Another research suggested that emotion deregulation can fully mediate low self-esteem and physical aggression; anger; and hostility (Garofalo, Holden, Zeigler-Hill, \& Velotti, 2016). According to the research in previous paragraph, it shows that emotion management is an important element which can help controlling student's aggression behavior. It is proven that the better someone's emotion management, the lower aggression behavior will be. In contrast, the tendency of aggression will be higher if someone has bad emotion management.

There are three skills which underlie emotion regulation. They are emotional awareness; acceptance; and strategies to control emotion (Roberton, Daffern, \& Bucks, 2012). These abilities can increase someone's ability to control their emotion more adaptively. Thus when someone can manage their emotion adaptively, aggression behavior will decrease significantly. Therefore, it becomes a pretention for someone to possess this ability so that their development can be more optimal.

Aggression behavior may result to a false perception about how bad school environment is for student. A research claimed that aggression behavior can be a pushing factor for a perception about school environment (Marsh, McGee, \& Williams, 2014). Another research also suggested that students who involve in bullying either as a doer or victim have a negative perception about school climate (Nickerson, Singleton, Schnurr, \& Collen, 2014). The increase of aggression behavior will equally trigger the emergence of negative perception about school environment. Therefore, special attention from many stakeholders comes as a response of aggression behavior and student inability to control their emotion.

Student's perception about school climate will influence student's motivation to achieve academic success significantly. A research showed that a good perception can bring positive influence towards student's academic achievement (Urick \& Bowers, 2014). Student's negative perception toward their environment (when intimidation; bullying; and violence happen) influence students' academic achievement and their well-being (Kutsyuruba, Klinger, \& Hussain, 2015). School climate is a important factor when student can feel save; connected; and supported either by friends or teachers. It then protects their mental and emotional health to achieve the best in school (Lester \& Cross, 2015). This explanation becomes an important thing for all stakeholders who are responsible to design the best school program to create conducive climate. Thus, students' well-being in their everyday activity can be well actualized and maximized for their academic success. 


\section{CONCLUSION}

The result of this research show that there is a difference in male and female student self-regulation of emotion ability. Female students have better emotion management than male. The finding in this research may be used as a recommendation for school, specifically counselor to design the strategy so that student's self-regulation ability can be improved after considering their gender.

\section{REFERENCES}

Alhadi, S., Purwadi, P., Muyana, S., Saputra, W. N. E., \& Supriyanto, A. (2018). Agresivitas Siswa SMP di Yogyakarta. Jurnal Fokus Konseling, 4(1), 93-99.

Gage, N. A., Adamson, R., MacSuga-Gage, A. S., \& Lewis, T. J. (2017). The Relation Between the Academic Achievement of Students with Emotional and Behavioral Disorders and Teacher Characteristics. Behavioral Disorders, 0198742917713211.

García-Sancho, E., Salguero, J. M., \& Fernández-Berrocal, P. (2017). Ability Emotional Intelligence and Its Relation to Aggression Across Time and Age Groups. Scandinavian Journal of Psychology, 58(1), 43-51.

Garofalo, C., Holden, C. J., Zeigler-Hill, V., \& Velotti, P. (2016). Understanding The Connection Between SelfEsteem and Aggression: The Mediating Role of Emotion Dysregulation. Aggressive Behavior, 42(1), 3-15.

Gomez-Baya, D., Mendoza, R., Paino, S., \& de Matos, M. G. (2017). Perceived Emotional Intelligence as A Predictor of Depressive Symptoms During Mid-Adolescence: A Two-Year Longitudinal Study on Gender Differences. Personality and Individual Differences, 104, 303-312.

Hofmann, S. G., Carpenter, J. K., \& Curtiss, J. (2016). Interpersonal Emotion Regulation Questionnaire (IERQ): Scale Development and Psychometric Characteristics. Cognitive Therapy and Research, 40(3), 341-356.

Hopkins, J. R. (2014). Adolescence: The Transitional Years. Academic Press.

Huesmann, L. R., Dubow, E. F., Boxer, P., Landau, S. F., Gvirsman, S. D., \& Shikaki, K. (2017). Children's Exposure to Violent Political Conflict Stimulates Aggression at Peers by Increasing Emotional Distress, Aggressive Script Rehearsal, and Normative Beliefs Favoring Aggression. Development and Psychopathology, 29(1), 39-50.

Jenkins, L. N., Demaray, M. K., \& Tennant, J. (2017). Social, Emotional, and Cognitive Factors Associated With Bullying. School Psychology Review, 46(1), 42-64.

Kutsyuruba, B., Klinger, D. A., \& Hussain, A. (2015). Relationships among School Climate, School Safety, and Student Achievement and Well-Being: A Review of The Literature. Review of Education, 3(2), 103-135.

Lester, L., \& Cross, D. (2015). The Relationship Between School Climate and Mental and Emotional Wellbeing Over The Transition from Primary to Secondary School. Psychology of Well-Being, 5(1), 9.

Marsh, L., McGee, R., \& Williams, S. (2014). School Climate and Aggression among New Zealand High School Students. New Zealand Journal of Psychology, 43(1), 28-37.

Nickerson, A. B., Singleton, D., Schnurr, B., \& Collen, M. H. (2014). Perceptions of School Climate As A Function of Bullying Involvement. Journal of Applied School Psychology, 30(2), 157-181.

Panjwani, N., Chaplin, T. M., Sinha, R., \& Mayes, L. C. (2016). Gender Differences in Emotion Expression in Low-Income Adolescents Under Stress. Journal of Nonverbal Behavior, 40(2), 117-132.

Perry-Parrish, C., Webb, L., Zeman, J., Spencer, S., Malone, C., Borowski, S., ... Ostrander, R. (2017). Anger Regulation and Social Acceptance in Early Adolescence: Associations with Gender and Ethnicity. The Journal of Early Adolescence, 37(4), 475-501.

Philippot, P., \& Feldman, R. S. (2004a). Cognitive Regulation of Emotion: Application to Clinical Disorders. In The Regulation of Emotion (pp. 86-113). Psychology Press.

Philippot, P., \& Feldman, R. S. (2004b). Positive Emotion and The Regulation of Interpersonal Relationships. In The Regulation of Emotion (pp. 142-171). Psychology Press.

Roberton, T., Daffern, M., \& Bucks, R. S. (2012). Emotion Regulation and Aggression. Aggression and Violent Behavior, 17(1), 72-82.

Routt, G., \& Anderson, L. (2011). Adolescent Violence Towards Parents. Journal of Aggression, Maltreatment \& Trauma, 20(1), 1-19.

Saputra, W. N. E., \& Handaka, I. B. (2018). Perilaku Agresi Pada Siswa SMK di Yogyakarta. Jurnal Fokus Konseling, 4(1), 1-8. 
Saputra, W. N. E., Hanifah, N., \& Widagdo, D. N. (2017). Perbedaan Tingkat Perilaku Agresi Berdasarkan Jenis Kelamin pada Siswa Sekolah Menengah Kejuruan Kota Yogyakarta. Jurnal Kajian Bimbingan dan Konseling, 2(4), 142-147.

Scott, L. N., Stepp, S. D., \& Pilkonis, P. A. (2014). Prospective Associations Between Features of Borderline Personality Disorder, Emotion Dysregulation, and Aggression. Personality Disorders: Theory, Research, and Treatment, 5(3), 278.

Shah, C. J., Sanisara, M., Mehta, H. B., \& Vaghela, H. M. (2017). The Relationship Between Emotional Intelligence and Academic Achievement in Medical Undergraduate. International Journal of Research in Medical Sciences, 2(1), 59-61.

Shelton, D., Sampl, S., Kesten, K. L., Zhang, W., \& Trestman, R. L. (2009). Treatment of Impulsive Aggression in Correctional Settings. Behavioral Sciences \& The Law, 27(5), 787-800.

Sointu, E. T., Savolainen, H., Lappalainen, K., \& Lambert, M. C. (2017). Longitudinal Associations of StudentTeacher Relationships and Behavioural and Emotional Strengths on Academic Achievement. Educational Psychology, 37(4), 457-467.

Spriggs, A. L., Iannotti, R. J., Nansel, T. R., \& Haynie, D. L. (2007). Adolescent Bullying Involvement and Perceived Family, Peer and School Relations: Commonalities and Differences Across Race/Ethnicity. Journal of Adolescent Health, 41(3), 283-293.

Sullivan, T. N., Garthe, R. C., Goncy, E. A., Carlson, M. M., \& Behrhorst, K. L. (2017). Longitudinal Relations between Beliefs Supporting Aggression, Anger Regulation, and Dating Aggression among Early Adolescents. Journal of Youth and Adolescence, 46(5), 982-994.

Trives, J. J. R., Bravo, B. N., Postigo, J. M. L., Segura, L. R., \& Watkins, E. (2016). Age and Gender Differences in Emotion Regulation Strategies: Autobiographical Memory, Rumination, Problem Solving and Distraction. The Spanish Journal of Psychology, 19.

Urick, A., \& Bowers, A. J. (2014). The Impact of Principal Perception on Student Academic Climate and Achievement in High School: How Does It Measure Up. Journal of School Leadership, 24(2), 386-414.

Valois, R. F., Zullig, K. J., \& Revels, A. A. (2017). Aggressive and Violent Behavior and Emotional Self-Efficacy: Is There a Relationship for Adolescents? Journal of School Health, 87(4), 269-277.

Vandekerckhove, M., Von Scheve, C., Ismer, S., Jung, S., \& Kronast, S. (2008). Regulating Emotions: Culture, Social Necessity, and Biological Inheritance. Wiley Online Library.

Wigelsworth, M., Qualter, P., \& Humphrey, N. (2017). Emotional Self-Efficacy, Conduct Problems, and Academic Attainment: Developmental Cascade Effects in Early Adolescence. European Journal of Developmental Psychology, 14(2), 172-189.

Zych, I., Farrington, D. P., Llorent, V. J., \& Ttofi, M. M. (2017). Personal Protective Factors Against Bullying: Emotional, Social, and Moral Competencies. In Protecting Children Against Bullying and Its Consequences (pp. 23-40). Springer. 